\title{
WYKORZYSTANIE WYNIKÓW SONDOWANIA STATYCZNEGO DO OKREŚLENIA NOŚNOŚCI POBOCZNICY PALA
}

\begin{abstract}
Praca jest kontynuacją badań Autorów nad modelem krzywej Meyera Kowalowa[8] opisującej zachowanie pala pod obciążeniem. W artykule podano propozycję opisu parametrów modelu krzywej MK w nawiązaniu do wyników sondowania CPT. W części obliczeniowej przedstawiono analizę zachowania pali przemieszczeniowych SDP pod próbnym obciążeniem statycznym, posiłkując się badaniami literaturowymi i własnymi. Autorzy proponują metodę określania nośności pobocznicy pala, którego podstawa jest zagłębiona w zagęszczone grunty niespoiste na podstawie wyników badań sondowania statycznego CPT, jednocześnie porównując wyniki otrzymane w analizie do wyników badań literaturowych i własnych. Zróżnicowane metody określania nośności podstawy pala na podstawie sondowania CPT prowadzą do otrzymania szeregu krzywych obrazujących nośność pobocznicy. Cechą wspólną tych krzywych jest występowanie maksimum dla oporu pobocznicy.
\end{abstract}

Słowa kluczowe: nośność pali, próbne obciążenia statyczne, badania terenowe, obciążenie-osiadanie pala

\section{Wprowadzenie}

\subsection{Uwagi ogólne dotyczące wykorzystania badań podłoża}

Projektowanie fundamentów palowych na bazie geotechnicznych właściwości podłoża jest jedną z zalecanych w Eurokodzie 7 a zarazem najpopularniejszych metod projektowania pali [16]. Obecnie prowadzone badania geotechniczne rzadko, składają się wyłącznie z samych odwiertów. Trendy dominujące w geotechnice wskazują, że podstawowymi badaniami będą badania in situ z wykorzystaniem sond statycznych, dylatometru Marchettiego czy statycznych sondowań sejsmicznych.

\footnotetext{
${ }^{1}$ Autor do korespondencji/corresponding author: Grzegorz Szmechel, ZUT w Szczecinie, al. Piastów 17, 70-310 Szczecin, gszmechel@zut.edu.pl

${ }^{2}$ Meyer Zygmunt, ZUT w Szczecinie, meyer@zut.edu.pl
} 
Doświadczenia światowe obejmują obecnie przeszło 60 lat badań nad rozwojem metod projektowania pali z użyciem sondy statycznej. Analiza literatury z zakresu obliczania nośności pali na podstawie testu statycznego pozwala na wyodrębnienie dwóch podstawowych typów metod określania nośności pali przy wykorzystaniu parametrów uzyskanych podczas sondowania statycznego:

- metody bezpośrednie, wśród których rozróżniamy metody empiryczne, pozwalające, na określenie oporu jednostkowego pobocznicy $f_{p}$ i podstawy $q_{b}$ na podstawie parametrów sondowania i metody półempiryczne wykorzystujące w analizie także inne parametry takie jak wartość całkowitych naprężeń pierwotnych, średnica, i długość pala, kąt tarcia na styku pal ośrodek gruntowy. Popularnymi metodami z tej grupy są: Metoda Meyerhofa [13,14,15], Metoda Francuska [1,2] czy metoda Niemiecka (2010)[5],

- metody pośrednie (tzw. metody wymierne), wśród których możemy z kolei wyodrębnić metody opisujące nośność pala w warunkach naprężeń całkowitych. W odniesieniu do oporów pobocznicy nazywane metodami $\alpha$, np. metodę Tomlinsona (1957), Randolpha (1983), Jamiołkowskiego (2003) czy Karslruda (2012). Drugą grupą metod bezpośrednich są metody bazujące na przyjęciu w gruncie naprężeń efektywnych (w odniesieniu do oporów pobocznicy pala zwane metodami $\beta$ ) wśród nich np. metodę Fleminga (1992) lub ICP-05 (2005) [5].

\section{Praca pala w gruncie}

\subsection{Propozycja opisu}

Wiadomo iż nośność pala jest wynikiem przenoszenia naprężeń zarówno przez pobocznicę jak i podstawę pala. Dotychczasowe badania prowadzone w Katedrze Geotechniki przez zespół prof. Meyera wskazują, iż jest możliwe rozgraniczenie pracy pala w ośrodku gruntowym na dwa stany: stan pierwszy, w którym pracuje tylko podstawa pala, oraz stan drugi, w którym pracuje zarówno jego podstawa jak i pobocznica. Zagadnienie to opisano już w literaturze $[7,8,9$ 11,17] Biorąc pod uwagę różnice wyników, jakie uzyskuje się wykorzystując do obliczenia nośności podstaw pali różne metody obliczeniowe, w pracy postanowiono sprawdzić, jaki wpływ różnice te będą miały na przebieg krzywej obciążenie-osiadanie pala w stanie 1 i 2 . Idea wykorzystania dwóch stanów pracy pala dla określania oporu pobocznicy pala, jako różnicy oporów pomiędzy stanem pierwszym i drugim została szerzej opisana w pracach Meyera [6], Meyera i Szmechela [7] oraz Meyera i Żarkiewicza [11]. Schematycznie sytuację pokazano na rys. 1

W niniejszej pracy podejście to wykorzystane zostanie do analizy wpływu metody obliczania nośności podstawy pala bezpośrednio z parametrów sondowania statycznego wg propozycji literaturowych: Metody Meyerhofa $[13,14,15]$, Metody Lee i Salgado [4] oraz Bustamante i Gianasellego [1,2], a także wg propozycji Autorów uwzględniającej współpracę podstawy pala $\mathrm{z}$ otaczającą tę podstawę przestrzenią gruntową. 
Nośność pala w klasycznym ujęciu jest rozumiana, jako nośność podstawy i pobocznicy wg wzoru [16]:

$$
Q_{t}=Q_{s}+Q_{b}=\sum f_{p i} \cdot A_{s i}+q_{b} \cdot A_{b}
$$

gdzie: $f_{p i}$ - jednostkowy opór pobocznicy w i-tej warstwie gruntu,

$A_{s i}-$ pole pobocznicy w tej warstwie,

$q_{b}-$ jednostkowy opór podstawy pala,

$A_{b}$ - pole podstawy pala.

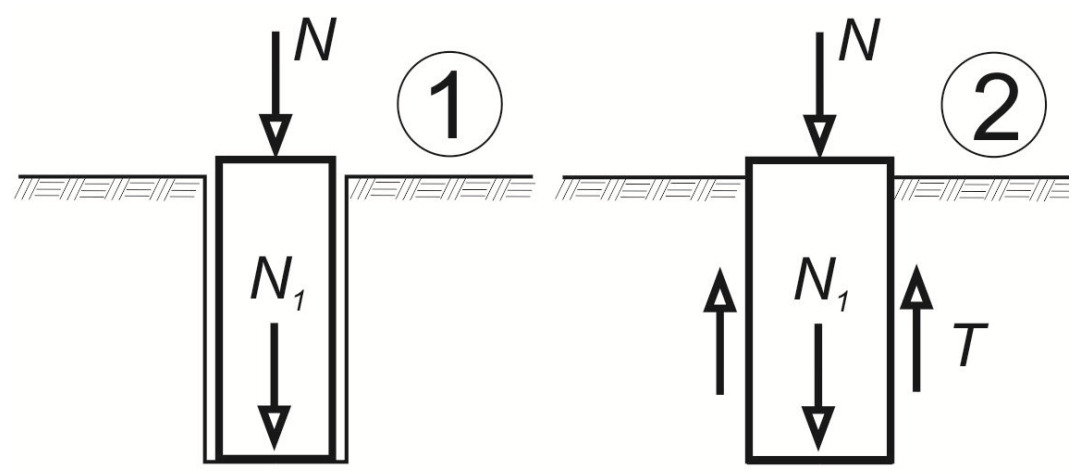

Rys. 1. Schemat pracy pala w dwóch stanach 1 i 2 [7]

Fig. 1. Schematic pile work in two different stages 1 and 2 [7]

Różnice w nośnościach podstaw pali uzyskane zostaną dzięki zastosowaniu 4 różnych metod określania odporu podstawy pala $q_{b}$. Natomiast opór pobocznicy traktuje się, jako różnicę pomiędzy siłą w stanie 1 i 2 :

$$
\begin{aligned}
& T=N\left(s_{2}\right)-N\left(s_{1}\right) \\
& T(s)=N_{g r} \cdot\left[1-\left(1+\frac{\kappa_{2} \cdot s}{C_{2 N g r}}\right)^{-\frac{1}{\kappa_{2}}}\right]-N_{1} \cdot\left[1-\left(1+\frac{\kappa_{1} \cdot s}{C_{1 N_{1}}}\right)^{-\frac{1}{\kappa_{1}}}\right]
\end{aligned}
$$
ności:

Parametry $C_{l}$ oraz $\kappa_{l}$ równania stanu pierwszego opisują empiryczne zależ-

$$
C_{1}=\frac{1}{\pi \cdot d \cdot 3 q_{c}}[\mathrm{~mm} / \mathrm{kN}]
$$

gdzie: $q_{c}$ - uśredniony wg [16] opór stożka pod podstawą pala [MPa],

$d$-średnica pala[m],

$$
\kappa_{1}=\frac{2}{3} \kappa_{2}^{2 / 3}
$$




\subsection{Nośność podstawy pala - wybrane metody literaturowe}

Metoda Meyerhofa $(1956,1976,1983)$

Może być stosowana dla pali przemieszczeniowych i wierconych w gruntach piaszczystych. Jednostkowy opór podstawy Meyerhof uzależnia od głębokości osadzenia pala $\mathrm{w}$ gruncie nośnym, długości samych pali, oraz układu warstw gruntu nośnego i nienośnego. Układ warstw gruntu i poszczególne oznaczenia pokazano na rysunku 2:

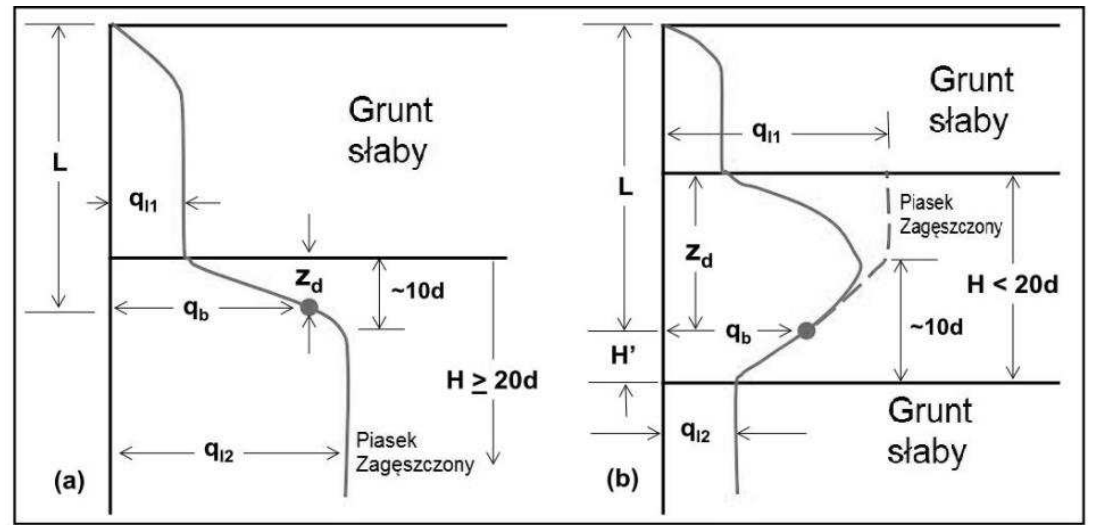

Rys. 2. Odpór podstawy pala w zależności od układu warstw nośnych: (a) znaczna miąższość warstwy piasków, (b) warstwa nośna naprzemiennie z warstwami słabszymi, na podstawie [14]

Fig. 2. Base resistance depended on soil layers arrangement (a) thick sand layer, (b) bearing layer alternate with soft soils, based on [14]

Dla warstw gruntu nośnego znacznej grubości zalegającego pod palem $H>20 d$ :

$$
q_{b}=q_{l 1}+\left(q_{l 2}-q_{l 1}\right) \cdot z_{d} /(10 d) \leq q_{l 2}[\mathrm{MPa}]
$$

gdzie: $z_{d}$-zagłębienie pala $\mathrm{w}$ warstwie nośnej [m],

$d$-średnica pala $[\mathrm{m}]$

Metoda Lee i Salgado (1999)

Kolejna z metod bezpośrednich wykorzystanych w niniejszej pracy to metoda Lee i Salgado zaprezentowana w 1999r. Metoda ta może być stosowana do wszystkich typów pali w gruntach piaszczystych. Autorzy nie podają procedury określania jednostkowego oporu pobocznicy a jedynie jednostkowy opór podstawy pala $q_{b}$ oraz opór podstawy pala odpowiadający przemieszczeniom $0,1 d$ [4]. 


$$
q_{b}=q_{t} /\left[1,90+0,62 /\left(s_{b} / d\right)\right][\mathrm{MPa}]
$$

gdzie: $q_{t}$-skorygowany opór stożka [MPa],

$$
q_{i}=q_{c} \cdot\left(1-a_{n}\right)
$$

gdzie: $a_{n}$ - współczynnik wielkości stożka zależny od rodzaju sondy i stożka CPTu,

$u_{2}$ - ciśnienie porowe mierzone za stożkiem $q_{c}$ - opór stożka [MPa]

Według badań Mayne’a [5] w gruntach niespoistych można przyjmować $q_{c} \approx q_{t}$ gdyż ciśnienie porowe $u_{2}$ równe jest ciśnieniu hydrostatycznemu.

\section{Metoda Francuska LPCP (tzw. metoda Bustamante $(1982,1997)$}

Metoda zaproponowana w 1982 r. przez Bustamante i Gianasellego w 1982 r. na podstawie 197 badań statycznych pali różnych typów w różnych warunkach gruntowych. Poulos w 1989 r. zaproponował graficzne podejście do obliczania jednostkowych oporów pobocznicy pala i podstawy pala oraz metod uśredniania wartości $q_{c}$ pod podstawą pala. Dokładne informacje dotyczące tych badań znaleźć można w pracy Poulosa [17]. W 1997 r. metoda została uproszczona przez Bustamante i Franka [1] na podstawie kolejnych badań. Jako jedna z niewielu metod różnicując tzw. „górne” i „dolne” wartości współczynników w zależności od wrażliwości konstrukcji.

Opór podstawy pala wg metody LPCP wyrażony jest równaniem:

$$
q_{b}=q_{e q(t i p)} \cdot k_{b}
$$

gdzie: $k_{b}$ - współczynnik nośności podstawy dla piasków $k_{b}=0,15$ pale wiercone i $k_{b}=0,375$ pale przemieszczeniowe,

$q_{e q(t i p)}$ - równoważny średni opór stożka liczony na długości $1,5 d$ poniżej i 1,5d powyżej podstawy pala (wg Bustamante I Gianeselli 1982).

\section{Propozycja Autorów}

Studia literaturowe i badania własne wskazują, że podstawa pala w stanie granicznym współpracuje z pewną przestrzenią gruntu znajdującą się $\mathrm{w}$ jej bezpośrednim sąsiedztwie wg schematu zaprezentowanego na rysunku 3.

Nośność podstawy pala wyrazić można wg następujących zależności:

$$
N_{1}=0,25 \cdot \pi \cdot d^{* 2} \cdot\left(q_{c}\right)
$$

gdzie: oznaczenia jak we wzorze (4)

$d *$ - średnica równoważna gruntu który w stanie granicznym współpracuje $\mathrm{z}$ palem, 


$$
d^{*}=\theta \cdot d
$$

gdzie: $\theta$-współczynnik poszerzenia podstawy zależny od rodzaju pali, i gruntu, w jakim zagłębiona jest podstawa pala. Dla pali przemieszczeniowych i gruntu niespoistego $\theta=\left(2 q_{c}\right)^{1 / 6}$.

Drugim podejściem, jakie można zastosować przy określeniu nośności podstawy pala jest określenie nośności podstawy pala, jako różnicy pomiędzy nośnością graniczną. Wyznaczoną z metody MK a nośnością pobocznicy pala także w stanie granicznym. Wiadomo, że istnieje pewna graniczna wartość odporu pobocznicy dla $s=\infty$ odpowiadająca $\mathrm{T}_{\infty}$. Dla celów inżynierskich obliczeń można ją wyrazić wzorem [7]:

$$
T_{\infty}=\pi d \sum h_{i} f_{s i} \text { lub } T_{\infty}=\pi d \int_{0}^{L} f_{s} d L[\mathrm{kN}]
$$

gdzie: $f_{s i}$ - opór tulei ciernej sondy statycznej w i-tej warstwie gruntu [kPa],

$h_{i}-$ miąższość warstwy gruntu [m],

$d$ - patrz str. poprz.

Wówczas graniczna nośność podstawy pala może być wyrażona za pomocą zależności (5) lub jako różnica pomiędzy:

$$
N_{1}=N_{g r}-\pi d \sum h_{i} f_{s i}
$$

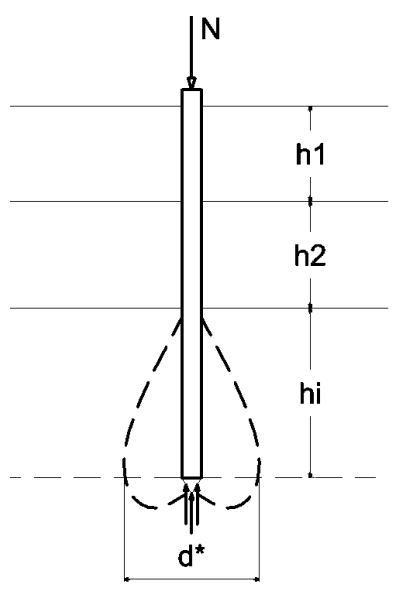

Rys. 3. Grunt współpracujący z podstawą pala w stanie granicznym

Fig. 3. Soil mass interacted with pile base in ultimate limit state 


\section{Przykład obliczeniowy}

\subsection{Badania literaturowe}

Jako przykład badań statycznych pali przemieszczeniowych dostępnych w literaturze wykorzystano cztery z wielu zaprezentowanych w monografii Krasińskiego [3]. Do analizy wykorzystano pale przebadane na poletku doświadczalnym „Obwodnica Pruszcza Gdańskiego” Oznaczone w pracy, jako SDC-b1 do SDC-b4. Pale te wykonane zostały jako przemieszczeniowe pale SDP o średnicy $360 \mathrm{~mm}$, i długościach od 7 do $9 \mathrm{~m}$. W ramach badań Krasińskiego przeprowadzono pomiar próbnego obciążenia statycznego z pomiarem siły osiowej wzdłuż pali przy wykorzystaniu czujników ekstensometrycznych [3]. Warunki gruntowe poletka scharakteryzowano wykorzystując szeroko opisane badania CPTu, przykładowe wyniki badań przedstawiono na rysunku 4.

W odniesieniu do wyników próbnych obciążeń statycznych pali SDC-b1 do b4 zastosowano procedurę Meyera Kowalowa określenia nośności granicznej $N_{g r}$, a następnie podjęto własną próbę określenia oporu pobocznicy poza zakresem przeprowadzonego próbnego obciążenia, wykorzystując wyżej opisane metody analityczne. Jako zmienną potraktowano tutaj nośność podstawy pala $N_{l}$ z uwagi na możliwość wykorzystania oporu stożka $q_{c}$ przy średnicy normalnej odpowiadającej średnicy pala, średnicy gruntu współpracującego z palem w stanie granicznym a także nośność podstawy będąca wynikiem zastosowania

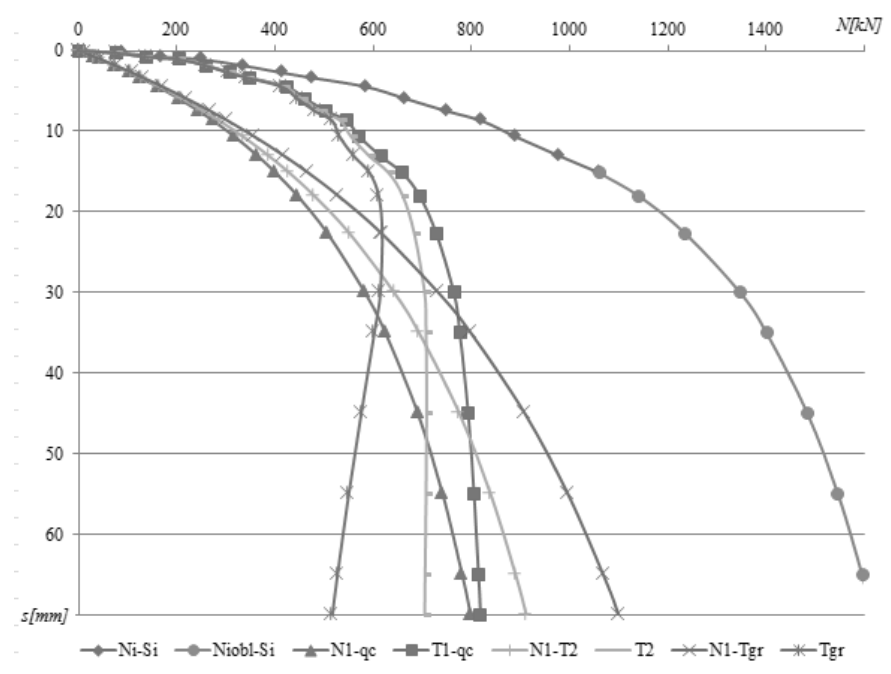

Rys. 4. Wyniki analiz dla pala SDC-b1 Objaśnienia: $N_{i^{-}} S_{i^{-}}$wartości pomierzone, $N_{\text {iobl }} S_{i^{-}}$ wartości ekstrapolowane metoda $M K, N 1, T 1$ nośność podstawy i opór pobocznicy pala odpowiednio dla wartości $q_{c}\left(N 1-q_{c}\right), q_{c}$ przy średnicy d*(N1-T2) oraz $T_{g r}$ wg wzoru (12)(N1-T $\left.T_{g r}\right)$

Fig. 4. Analysis results for SDC-b1 pile. Symbols used: $N_{i}-S_{i}$ - measured values, $N_{\text {iobl }} S_{i}-M K$ extrapolation, N1,T1 base and shaft resistance for $q_{c}\left(N 1-q_{c}\right), q_{c}$ with larger dimension $d^{*}(N 1-T 2)$ and $T_{g r}$ according to formula $(12)\left(N 1-T_{g r}\right)$ 
zależności (13) przy wykorzystaniu wykresu $f_{s}$ dla $T_{g r}$. Otrzymane wielkości oporu podstawy dla odpowiadającego im osiadania porównano $\mathrm{z}$ wielkościami z badań Krasińskiego [3]:

Wyniki analizy zestawiono w Tabeli 1, oraz pokazano na rysunkach 4-5.

\subsection{Badania własne}

Przykładowe obliczenia wykonano dla 2 pali SDP formowanych w gruncie wykonanych podczas budowy budynku biurowego na terenie województwa Zachodniopomorskiego, warunki gruntowe w formie wyników sondowań CPT przedstawiono na rysunku 7 wraz z krzywymi obciążenie-osiadanie uzyskanymi podczas próbnych obciążeń. Parametry uzyskane z modelu MK wynoszą: dla pala 299: $C_{2}=0,0041 \mathrm{kN} / \mathrm{mm}, N_{g r 2}=2557 \mathrm{kN}$, oraz $\kappa_{2}=2,65$ dla pala 994: $C_{2}=0,0038 \mathrm{kN} / \mathrm{mm}, N_{g r 2}=2043 \mathrm{kN}$, oraz $\kappa_{2}=2,05$.

Średnica pali SDP wynosiła $400 \mathrm{~mm}$, długość obu pali ok. 9,0m. Pale te zagłębione były w warstwie wierzchniej do około $3.0 \mathrm{~m}$ p.p.t. w nasypy niekontrolowane słabe, pod nasypami, do głębokości około $5.0 \mathrm{~m}$ p.p.t. znajdowały się grunty słabonośne w postaci namułów i torfów. Podłoże pod torfami zbudowane jest z piasków drobnych i średnich w stanie średnio zagęszczonym oraz zagęszczonym. W piaskach występują soczewki gruntów pylastych (piaski pylaste, glina pylasta). Ustabilizowane zwierciadło wody gruntowej podczas badań znajdowało się na głębokości od około 0.2 do około $0.8 \mathrm{~m}$ p.p.t. tj. na poziomie od około 1.7 do 2.2 m n.p.m.

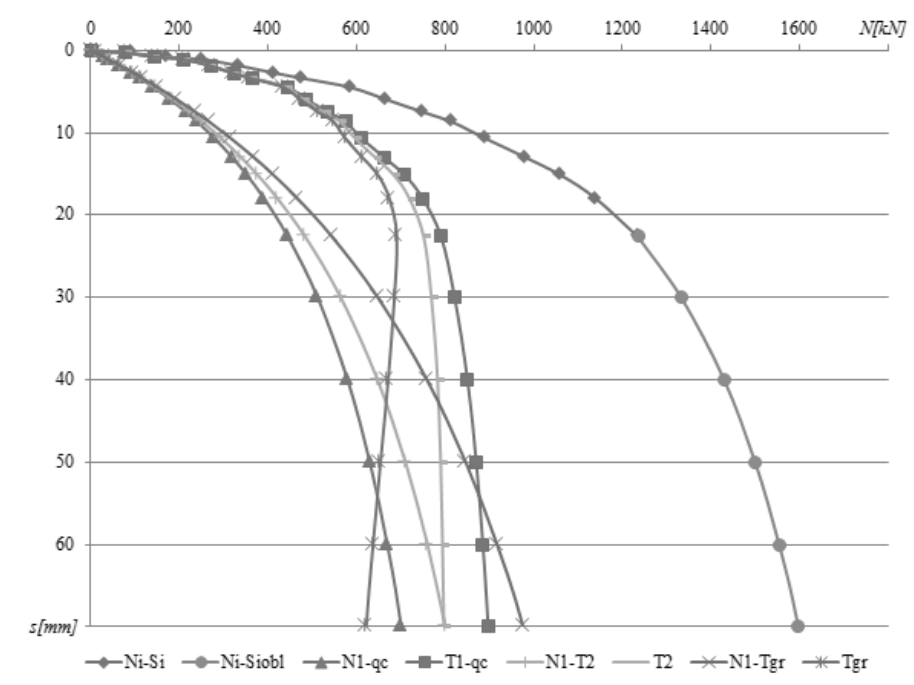

Rys. 5. Wyniki analiz dla pala SDC-b3 (oznaczenia jak w rysunku 4)

Fig. 5. Analysis results for SDC-b3 pile (used symbols as in Fig. 4) 

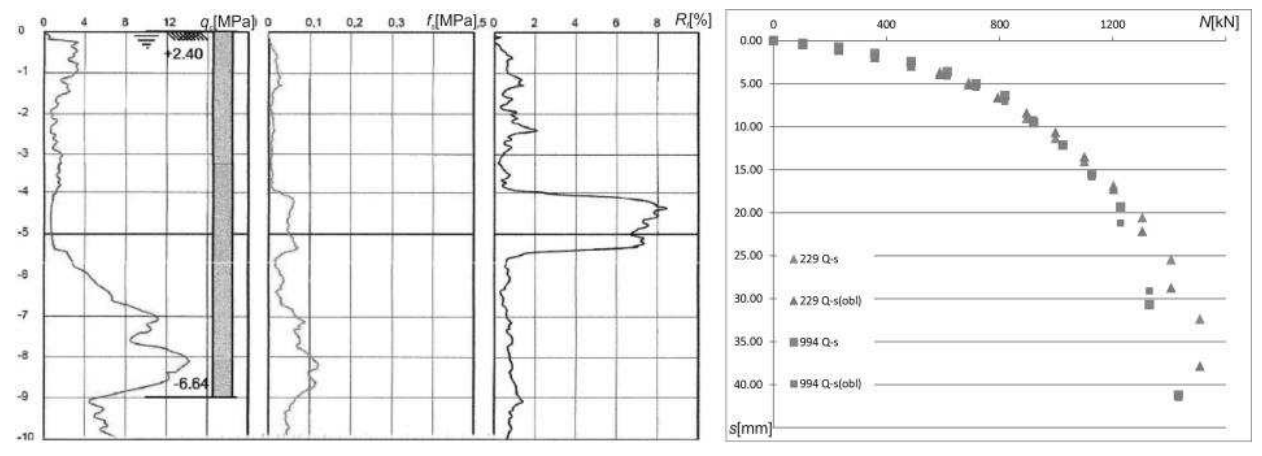

Rys. 6. Wyniki badań CPT i krzywe próbnego obciążenia (określone analitycznie i podczas próbnych obciążeń statycznych) dla pali SDP D=400mm

Fig. 6. CPT test results for SDP piles; SPLT curves results and MK interpolation

Następnie wykorzystując wcześniej podane zależności (2), (3), (4), (5), (10) i (13) obliczono parametry stanu pierwszego tj. wówczas, gdy pal pracuje tylko podstawą. W ten sposób uzyskano współczynniki $C_{l}, N_{g r l}$, oraz $\kappa_{1}$.

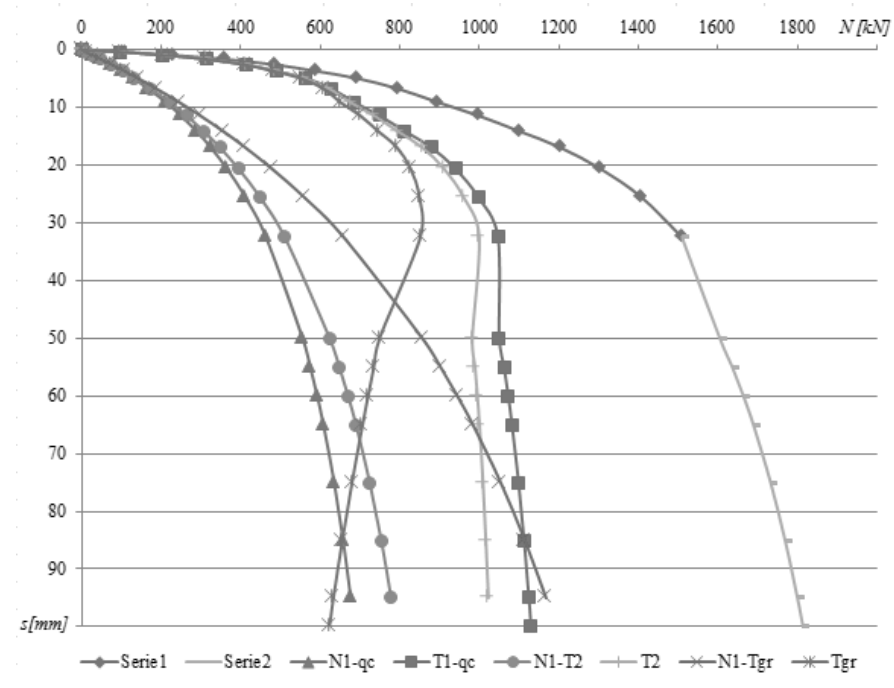

Rys. 7. Zmiana nośności pobocznicy pala dla różnych wartości nośności podstawy dla pala SDP 299, d=400mm (oznaczenia jak w rysunku 4)

Fig. 7. Shaft capacity changes, for different pile base capacities for SDP 299 pile, d=400mm (used symbols as in Fig. 4) 


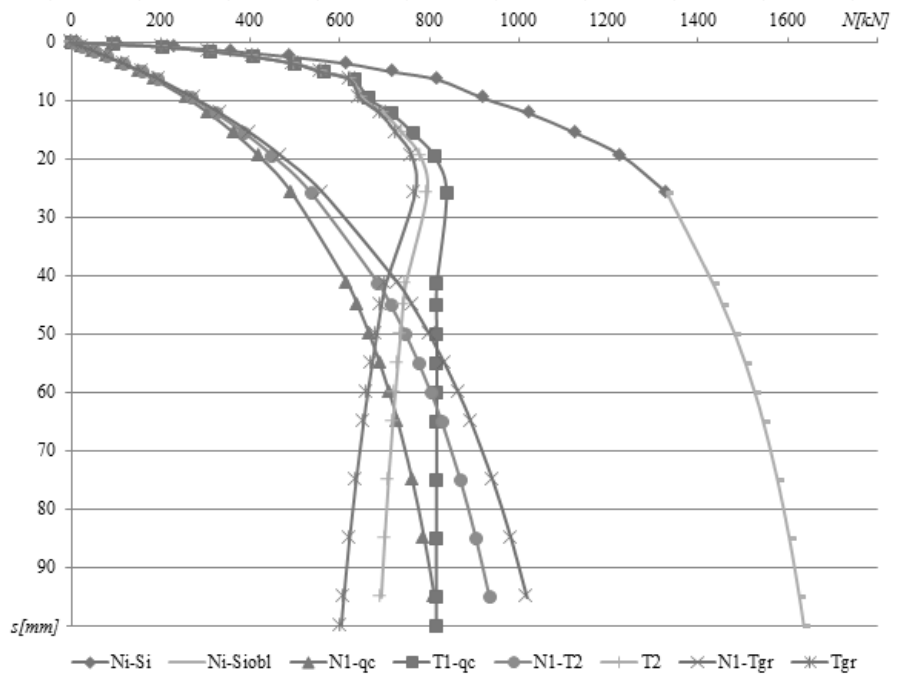

Rys. 8. Zmiana nośności pobocznicy pala dla różnych wartości nośności podstawy dla pala SDP 994, d=400mm

Fig. 8. Shaft capacity changes, for different pile base capacities for SDP 994 pile, d=400mm (used symbols as in Fig. 4)

Jako uzupełnienie analizy, wykonano obliczenia nośności podstaw pali metodami Meyerhofa, LPCP (met. Bustamante) oraz Lee i Salgado opisanych wcześniej. Wyniki porównania przedstawia tabela:

Tabela 1. Wyniki analizy

Table 1. Analysis results

\begin{tabular}{|c|c|c|c|c|c|c|c|c|}
\hline \multirow[t]{2}{*}{ Nr Pala } & \multirow{2}{*}{$\begin{array}{l}Q_{b^{-}}[3] \\
{[k N]}\end{array}$} & \multirow{2}{*}{$\begin{array}{l}S\left(Q_{b}\right) \\
{[\mathrm{mm}]}\end{array}$} & \multicolumn{3}{|c|}{$\begin{array}{c}\text { Opór podstawy pala wg. Auto- } \\
\text { rów }\end{array}$} & \multicolumn{3}{|c|}{ Opór podstawy pala wg } \\
\hline & & & $\begin{array}{c}N_{l}\left(q_{c}\right) \\
{[\mathbf{k N}]}\end{array}$ & $\begin{array}{c}N_{I}\left(q_{c}\right) d^{*} \\
{[\mathbf{k N}]}\end{array}$ & $\begin{array}{c}N_{l}\left(T_{g r}\right) \\
{[\mathbf{k N}]}\end{array}$ & $\begin{array}{c}\text { Mey- } \\
\text { erhofa } \\
{[\mathrm{kN}]}\end{array}$ & $\begin{array}{c}\text { LPCP } \\
\text { (Busta- } \\
\text { mante) } \\
{[\mathrm{kN}]}\end{array}$ & $\begin{array}{c}\text { Lee } i \\
\text { Salgado } \\
{[\mathrm{kN}]}\end{array}$ \\
\hline SDCb1 & 385 & 18,0 & 446 & 480 & $\begin{array}{l}539 \\
\end{array}$ & 460 & 365 & 292 \\
\hline SDCb2 & 310 & 14,3 & 402 & 429 & 444 & 475 & 391 & 308 \\
\hline SDCb3 & 320 & 15,1 & 352 & 376 & 412 & 407 & 326 & 254 \\
\hline SDCb4 & 279 & 11,7 & 288 & 305 & 323 & 391 & 313 & 244 \\
\hline SDP299 & - & 20,6 & 365 & 394 & 478 & 375 & 304 & 246 \\
\hline SDP 994 & - & 19,3 & 418 & 449 & 468 & 435 & 352 & 270 \\
\hline
\end{tabular}

\section{Podsumowanie}

W pracy przedstawiono analizę krzywych obciążenie-osiadanie dla pali przemieszczeniowych SDP z badań literaturowych i własnych. Przeanalizowano 
łącznie 6 pali przemieszczeniowych zagłębionych w zbliżonych warunkach gruntowych i wodnych, o podobnych długościach i średnicach. Analizując przedstawione wyniki, można zauważyć, iż nośności podstaw pali określone w sposób proponowany przez Autorów w odniesieniu do nośności podstawy pala podanej wg wzoru (10) mieszczą się w zakresie wartości otrzymanych wg metody Meyerhofa, oraz sa niewiele większe od pomierzonych $\mathrm{w}$ badaniach rzeczywistych [3]. Inne metody literaturowe jak metoda Bustamante [1,2] oraz Lee i Salgado [4] zawierają szereg współczynników redukujących nośność podstawy pala, tak, aby nadać jej pewną bezpieczną wartość charakterystyczną. Zdaniem autorów współczynniki takie nie mogą mieć zastosowania przy analizie pracy pala w stanie granicznym, tj. w momencie, gdy nośność graniczna traktowana jest, jako asymptota pionowa krzywej $N_{i}-s_{i}$.

Główną intencją Autorów referatu, było wskazanie, iż bez względu na sposób określania nośności podstawy pala krzywa obrazująca nośność pobocznicy charakteryzowana jest przez pewne ekstremum. Miejsce występowania tego ekstremum niezależnie od przyjętej metody odpowiada praktycznie pewnemu osiadaniu krytycznemu, którego to osiadania obciążany pal nie powinien przekraczać. W pracy przedstawiono także propozycję obliczania oporu pobocznicy pali przemieszczeniowych $\mathrm{w}$ stanie granicznym, na podstawie danych uzyskanych z próbnego obciążenia statycznego pali i wykonanego w jego sąsiedztwie sondowania statycznego wg wzoru (13), należy jednak pamiętać o tym, że aby wykorzystać w praktyce inżynierskiej zachowanie pala w stanie granicznym, należy zastosować odpowiednio duży współczynnik bezpieczeństwa.

Dalszej walidacji i weryfikacji w badaniach terenowych lub laboratoryjnych wymaga przebadanie zależności pomiędzy parametrami pracy pala $\mathrm{w}$ stanie pierwszym i drugim, a zwłaszcza parametrem kappa dla obu stanów. Prezentowane obliczenia, pomimo iż zawierają szereg założeń i zależności empirycznych wydają się dawać rezultaty oczekiwane i obserwowane w praktyce inżynierskiej.

\section{Literatura}

[1] Bustamante M, Frank R (1997) Design of axially loaded piles-French practice. In: Design of axially loaded piles - European practice, Proceedings of the ERTC3 seminar, Brussels, Belguim, Balkema, Rotterdam, The Netherlands: 161-175.

[2] Bustamante M, Gianeselli L.: (1982) Pile bearing capacity predictions by means of static penetrometer CPT. In: Proceedings of 2nd European symposium on penetration testing (ESOPT-II), Amsterdam, pp 493-500.

[3] Krasiński A.:(2013) Pale przemieszczeniowe wkręcane. Współpraca z niespoistym podłożem gruntowym. Wydawnictwo Politechniki Gdańskiej, Gdańsk.

[4] Lee JH, Salgado R.: (1999) Determination of pile base resistance in sands. J Geotech Geoenviron Eng 125(8):673-683.

[5] Mayne P.W.:(2007) Cone penetration testing - a synthesis of highway practice. NCHRP Synthesis 368, Transportation Research Board, Washington, DC, 117 p.

[6] Meyer Z, Kowalów M, i in.: (2015) Optymalizacja warunków posadowienia dużej hali produkcyjnej na przykładzie budowy fabryki samochodów marki Volkswagen we Wrześni. XXVII Konferencja Naukowo Techniczna Awarie Budowlane, Szczecin- Międzyzdroje. 
[7] Meyer Z, Szmechel G.: (2015) Określenie nośności pobocznicy pala na podstawie próbnych obciążeń statycznych. XXVII Konferencja Naukowo Techniczna Awarie Budowlane, Szczecin- Międzyzdroje.

[8] Meyer Z., Kowalów M.: (2010) Model krzywej aproksymującej wyniki próbnych obciążeń pali. Inżynieria Morska i Geotechnika Nr 3/2010.

[9] Meyer Z., Szmechel G.: (2012) Metoda interpretacji próbnych obciążeń pali prefabrykowanych. Materiały na 58, KN Krynica. Zeszyty Politechniki Rzeszowskiej.

[10] Meyer Z., Żarkiewicz K.: (2014) Wykorzystanie wzoru na osiadanie płyty statycznej do określenia naprężenia pod podstawą kolumny betonowej. Inżynieria Morska i Geotechnika, 01/2014, s. 30-35.

[11] Meyer Z., Żarkiewicz K.: (2015) Analiza współpracy pala z gruntem w dużym zakresie osiadania. XXVII Konferencja Naukowo Techniczna Awarie Budowlane, SzczecinMiędzyzdroje.

[12] Meyer Z.: (2010) Analiza naprężeń na pobocznicy oraz pod podstawą pojedynczego pala w oparciu o liniową teorię Boussinesqa. XVIII Seminarium Naukowe z cyklu Regionalne problemy inżynierii środowiska. Szczecin.

[13] Meyerhof GG.: (1956) Penetration tests and bearing capacity of cohesionless soils. ASCE J Soil Mech Found Div 82, pp 866-1019.

[14] Meyerhof G.G.: (1976) Bearing capacity and settlement of pile foundations. J Geotech Eng Div 102:195-228.

[15] Meyerhof G.G.: (1983) Scale effects of ultimate pile capacity. J Geotech Eng 109:797-806.

[16] PN-EN 1997-1. Eurokod 7 Projektowanie Geotechniczne, cz.1 Zasady ogólne.

[17] Poulos H.G.: (1989) Pile behavior: theory and applications. Rankine Lecture, Géotechnique 39(3):363-415.

[18] Szmechel G.: (2014) Określenie nośności granicznej pali na podstawie próbnych obciążeń statycznych w ograniczonym zakresie. Praca doktorska. Wydział Budownictwa i Architektury ZUT w Szczecinie.

\section{CONE PENETRATION TEST USED TO ESTIMATE PILE SHAFT RESISTANCE}

\section{S u m m a r y}

Paper presents the proposal of modelling the shaft of pile resistance, by using of Meyer Kowalow method. Meyer Kowalow method is known as a method of static pile load test interpretation. It was well presented in literature by Meyer and Kowalow[8], Meyer and Szmechel (2011), Meyer (2013), Szmechel[18]. Meyer Kowalow method is mainly used to predict ultimate bearing of the pile. During the analysis of pile load settlement curve we get also additional coefficients like C, and $\kappa$. It's probable that those additional coefficients are directly bounded with soil properties. According to this, parts of MK coefficients are taken directly from cone penetration test results as a proposal.

Authors want to use of MK method to predict changes of shaft of the pile resistance, in case when the pile base is recessed in very dense noncohesive ground. For this case it is possible to assume that pile works separately in two different cases. In case one only base of the pile takes part of the pile resistance and when the case two is realized both shaft and base works together.

Paper presents six different cases of pile behavior under static pile load test, their settlement and shaft base-relation resistance analysis for practical cases of pile foundation.

Keywords: pile capacity, SPLT, in situ tests, load settlement curve

Przestano do redakcji: 07.06.2016 $r$.

Przyjęto do druku: 30.06 .2016 r.

DOI: $10.7862 / \mathrm{rb} .2016 .66$ 